\title{
Historicism's Forms: The Aesthetics of Critique
}

In 1989, in an essay called "The History of the Anecdote: Fiction and Fiction,” Joel Fineman undertook an analysis of what he called "The formal operation of the anecdote, understood as a specific literary genre” (Fineman 1989, 50) and thus also of what he called "the characteristic writing practice of the New Historicism those essays that begin with an anecdote" (64). Fineman's interest was in the way that the foregrounding of the anecdote (his example was Stephen Greenblatt) took up a problem that had been central to historiography since its beginning, in Thucydides, where the problem of how to locate the anecdote - "the narration of a single event" that "uniquely refers to the real" (56) - in some "logic of sequential and transitional necessity" (53) was, he argued, first posed. And the central point of his essay was to assert the aporetic relation between the anecdote's claim on the real and the logic of transition, the way in which the anecdote's opening to "contingency" is, he says, closed off by its opposite, the "transitional necessity" that gives it "historical significance" (53).

Two years later, in the "Theory" chapter of Postmodernism, Fredric Jameson also undertook an analysis of what he called not the "writing practice" but the "writing convention" or "aesthetic" (Jameson 1991, 188) of the new historicism and he too focused on the question of transition while saying nothing, however, about the anecdote. For Jameson, the problem in new historicism was not exactly how to get from the anecdote to the larger historical narrative, it was how to construct a relation between literary texts and what he called the analyses of "a dazzling heterogeneity of raw material" ("medicine, gambling, land tenure, masochism, slavery, photography, contracts" etc.) (193) without producing such a narrative - without a story about how one thing caused the other or was about the other. And the new historicist aesthetic, in which "Elegance [...] consists in constructing bridge passages between the various concrete analyses, transitions [...] inventive enough to preclude the posing of theoretical or interpretive questions" (188) was its solution to this problem, its way of refusing or avoiding the "theoretical" question of how these analyses were connected.

For the purposes of a volume on poetic critique, my initial interest here is in the idea - taken usefully for granted in both these texts - that a mode of criticism might be said to have an aesthetic. So we do not have to worry about making it poetic, it already (for better or for worse) is. But my more basic interest is in the idea that transition is the formal problem the new historicism is seen to confront or the solution it is seen to deploy. And that interest, I should confess, is in part personal - since it was mainly the question of transitions in my book The Gold Standard and the Logic of Naturalism that Jameson was interested in and since it seems to me that re-raising that question might help me understand something a few people have 
asked me about and that I have asked myself - the relation between the Gold Standard's 1987 account of the work of art as entirely embedded in its culture and having therefore no critical distance from it and The Beauty of a Social Problem's account (in 2015) of art as providing just the kind of opportunity for critical understanding that The Gold Standard denied art could or did do (cf. Michaels 1987 and Michaels 2015). And if, with respect just to those two books, this question is at most of limited interest, it has, I think, a more general application. For if, as we have already seen, the new historicism was understood right from the start to have an aesthetic, that aesthetic should also be understood to have a history. And we can very quickly identify what will prove to be one salient aspect of that history by noting that the moment of the new historicism's emergence was the moment also of the emergence of neoliberalism and the take-off point in the U.S. for the new economic inequality. 1968 was the most equal year on record; the Gini coefficient ( 0 is perfect equality; 1 , one household has everything) was .38; by 1983, when the first issue of Representations (at the time a kind of founding organ of the new historicism) appeared, it had risen to a little over .41; in 2018, it was .49, the highest ever recorded (so far).

Of course, to characterize the rise in economic inequality as belonging to the history of an aesthetic might in itself seem problematic - just another exercise in the hermeneutics of suspicion which (no doubt because it never existed) has been essential to the rise of postcritique. But there are also more interesting objections. Think of Adorno criticizing Benjamin for his "tendency to relate" - "immediately and perhaps even causally" - some of the "features" of Baudelaire's work "to adjacent features in the social history of his time, preferably economic features" (Adorno 1980, 128-129). What would it mean to "relate" formal features of the new historicist aesthetic (the anecdote, the transition) "immediately" to an adjacent feature of our social history like the redistribution of income upwards that began in the late 70 s?

The possibility of answering this question - in "perhaps even causally," I can feel my own as well as Adorno's fear of base and superstructure! - is further complicated by the fact that probably none of the Berkeley new historicists was the slightest bit aware of the supposedly determinative economic event that was taking place. So any account of its relevance to them would have to contend with their ignorance of it. But the interest in trying to raise it again is intensified by the fact that at least one of the formal features, the transition, can be understood, as Jameson had already begun to suggest, as a way of trying not to raise it. On his account, nothing is more characteristic of the new historicist aesthetic than juxtapositions of literary features like Frank Norris's McTeague being both a miner and a dentist (two professions intertwined by the fact that the miner takes gold out of the earth to put it into circulation, whereas the dentist takes gold out of circulation to put it into people's mouths) with economic ones like the political battles over whether the U.S. should stick to the gold standard or monetize silver (with its default consensus on the necessity of money with "intrinsic" value as opposed to dollar bills with none). And then with the effort to put both the dentist and the gold-bug into relation with the popularity of trompe l'oeil painting (which seeks to describe representational paintings as, like dollar bills, a form of 
deception) and with the fact that Trina McTeague is a miser about whom it is impossible to tell whether her love of money depends upon denying its status as a representation or fetishizing its status as a representation. How can we theorize the connection between trompe l'oeil painters and hard money Democrats, much less the connection of any of them to the novel?

The crucial thing for Jameson is what is not said: it is not said (in fact, it is explicitly denied) that the novel is about the gold standard and no theory of mediation that might explain how one could connect up the practice of dentistry with the vogue for a certain kind of painting, or pamphlets on free silver to novels that never even mention it is ever proffered. Indeed, as Jameson says, "elegance" consists in not providing these things. More generally, there's no account of what makes one historical context more relevant than another to the literary text - which is the problem that Fineman understands the anecdote to deconstruct. Rather the very idea of the relation between text and context seems to be refused and replaced by the effort to produce a criticism in which history figures but precisely not as context, not as a kind of explanatory background. In this criticism there is no background and not much in the way of explanation either - everything is foreground, and is made relevant by the mode of presentation rather than by some theoretical justification.

So, why? What was the attraction of that aesthetic? One answer would be that it works to prove what was widely taken (not least by the new historicists themselves) to be the new historicist point - that all these phenomena are so equally a part of capital's dispositif that it makes no sense to select one of them - literature - and confer on it a distinctively oppositional potential. Jameson generously says that when the transitions work, the reader is left with "a sense of breathlessness, of admiration for the brilliance of the performance, but yet bewilderment, at the conclusion of the essay, from which one seems to emerge with empty hands - without ideas and interpretations to carry away with us" (Jameson 1991, 188), a point that in a recent issue of American Literary History is put with less charity but equal accuracy by Francesca Sawaya when she refers to The Gold Standard in particular as "exasperatingly tautological and deterministic" (Sawaya 2019, 305). The tautology - the dentist is the miser is the trompe l'oeil painter - is what you get instead of the interpretation. On this account, whether you are left breathless or exasperated, what you are being told is that art cannot produce a reflection on capitalism, it can only participate in it (that would be also the determinism).

For Jameson, however, it is the tautological transitions that matter rather than the thesis they are supposed to serve. In fact, he focuses on the aesthetic precisely because he regards the thesis as of secondary interest - it is a pretext for producing the transitions, for motivating "the device" (Jameson 1991, 189). Hence, the question we just asked - what is the attraction of the transitions? - cannot be answered by invoking the argument they are supposed to prove.

How, then, can it be answered? Fineman reads the transition as a problem, not a solution. The appeal of the anecdote is in its ability to "produce the effect of the real" (Fineman 1989, 61) (which is what history demands) but, insofar as the real is iden- 
tified with what he calls "the occurrence of contingency" (61), the anecdote disrupts what history also demands - a "logic of sequential and transitional necessity" (53). Hence, he thinks, there is a fundamental discrepancy between the "experience of history" (53) as offered by the anecdote and the "estranged distance from the anecdotal real" (63) required by the logic of historicism, and the power of the anecdote is precisely the problem it produces: it resists transition - it marks the moment in the constitution of what he calls the "subject of history" (62) that is transcended but not fully subsumable by the "logic" (53) of historicism.

But Jameson's proof text (The Gold Standard) invokes the "logic," not the "subject" of its history, and the juxtaposition with Fineman helps us to see that what it was resisting (what made the tautology - this is this, as opposed to this explains this or this leads to this - attractive) was precisely what Fineman valued. Fineman valued the disruption of the relation between text and context because it was in that disruption that the subject's experience of the real emerged - the moment before contingency is subsumed by historical necessity, the moment when you cannot say why this is the right context in which to understand that, why this event is the background that helps us understand this text in the foreground. By contrast, The Gold Standard sought not to disrupt the relation between text and context but to iron out the difference between them, so that there would be no foreground or background, which is to say, no position from which some things looked closer and others farther away, which is to say no point of view, which is to say, no subject. If Fineman thought that history's logic condemned you to an "estranged distance from the anecdotal real," what The Gold Standard wanted from naturalism's logic was neither distance nor proximity (which after all are both positions of the subject). It wanted not the non-existence but the irrelevance of the subject.

Thus we have two versions of new historicist aesthetics, and although neither is in any way current today, it is not hard to see that Fineman's commitment to the subject - albeit in a domesticated and completely moralized form - has flourished. Indeed, at the heart of what we now call postcritique is a version of that commitment so complete it requires us to treat everything as at least what Latour calls a "quasisubject” (Latour 2014, 5-6) and hence, in Rita Felski's words, to put "people, animals, texts and things on a similar ontological footing" (Felski 2015, 184) in order to "emphasiz[e] their interdependence" (164) and thus "the agency of both texts and readers" (165). And if, at the root of this ontological egalitarianism is Latour's studied obliviousness to the difference between natural and non-natural signs (to use a Gricean example, the difference between the way the spots on your face mean measles and the way the phonemes "measles" mean measles ${ }^{1}$ ), its real rele-

1 Perhaps studied obliviousness is not quite right, since the main point of Latour's idea of agency is that it is supposed to call into question distinctions like the one between natural and non-natural signs. Sometimes he does this by insisting that meaning is "a property of all agents" (Latour 2014, 13) and thus central to both (which is uncontroversially true: "measles" means measles; spots mean measles); sometimes he does it by suggesting that the "word" "meaning" "be dropped altogeth- 
vance for my purpose is not this conceptual confusion in itself but the way the actornetwork theory it enables underwrites, for Felski, a model of the social that begins with the "sociology of the individual" and "ways of thinking about individuals" that do not "flatten and reduce them" (Felski 2015, 171-172).

There is a kind of aesthetic at work here too, not so much in the writing perhaps as in the expression of taste - what Felski wants is a world made up of the novel's round characters, those who, in a humanistic version of Fineman's insistence on "contingency," embody what E.M. Forster called "the incalculability of life" (Forster 1956, 78) and what Felski calls "the ever-present possibility of being surprised" (Felski 2019). ${ }^{2}$ Thus, for example, as against a "melancholic Marxism" that sees "economic interests" everywhere, she praises what she thinks of as sociology's more Latourian concept of "society" as "highly variegated and differentiated, made up of many kinds of institutions, communities, norms and behaviors." And against what she takes to be too easy a commitment to "the language of structure," she complains that Leavisites did not and Marxist literary critics (all nine of them) do not think about "how structure is to be defined" or "what kind of analytical work it does" (Felski 2019).

But here the very crudest possible analytical work Marxism does - understand society in terms of capital and labor - is of some use. Postcritique's picture of the social is the intersubjective (or, to use one of Felski's preferred terms, the "relational"), which is also the neoliberal picture and is, in fact, its therapy for any members of the working class who might have been made a little melancholic by the rising inequality I mentioned above. The treatment is just to understand that in political economy there really is no such thing as the working class. Indeed, from Foucault's analysis of how the concept of human capital turns the worker into a capitalist (and thus turns his salary into a return on that capital) to the Uber contract that operationalizes Foucault's analysis by turning employees into "independent contractors," a crucial feature of neoliberalism has been its commitment to making the structural - structural instead of relational, instead of intersubjective - antagonism between capital and labor disappear. It thus replaces the problem of structural injustice - exploitation - with an array of individual injustices (as variegated and differentiated as intersectional analysis can make them), but all marching under the banner of discrimination. Theoretical sophistication here consists precisely in infinitely multiply-

er" and that we talk instead about "path-building, or order-making, or creation of directions" instead, which relieves us from having "to specify if it is language or objects" we are analyzing and endows "things" with the "dignity of texts" while "elevating" texts "to the ontological status of things" (Latour 1996, 10). But, whichever words we use and whoever gets to be the most dignified, the difference between the spots (which are a symptom) and the word (which is a name) remains. As the fact that using the word does not require us to be sick while having the spots does reminds us.

2 For the complete quote, see Forster 1956, 78: “The test of a round character is whether it is capable of surprising in a convincing way [...]. It has the incalculability of life about it - life within the pages of a book." 
ing the number of subject positions any of us might occupy, while at the same time guaranteeing that they are just that - positions of the subject. And the success of this program is demonstrated every time someone insists, for example, that the tension between a class politics and an identity politics is specious because class is an identity too. ${ }^{3}$

Felski herself was an early adopter of class as identity (albeit a "negative" one) in her important (and fun to read) article "Nothing to Declare: Identity, Shame, and the Lower Middle Class" (Felski 2000). Here, her focus "on the psychic as well as the social, semiotics as much as economics" (34) is presented as a methodological rather than an ontological commitment. But actor-network theory would do for literary criticism what intersectionality has done for politics - take the idea of an essentially impersonal structure right out of it. In this respect, it is striking that all the different versions of postcritique especially have it in for Jameson, who keeps seeing not class identity, but class struggle in texts where it does not belong. And it is striking also that what Felski calls "everyday" reading and especially the kind of reading that goes on in the classroom provide her with an alternative model for interpretation as "the coproduction between actors" (12). You do not have to be a very suspicious reader to notice that for university professors teaching our students the relational virtues of what Latour calls "the care for phenomena" - sympathy, empathy, recognition - is redescribable (or really just describable) as teaching the sons and daughters of the upper class the responsibilities appropriate to the beneficiaries of the class system: how to appreciate their agency and use it humanely, how to exercise the privilege of checking their privilege. ${ }^{4}$ Obviously, using our privilege humanely is a virtue (the alternative is Trump), but, also obviously, it is a way of living with inequality, not combatting it, of keeping the essential antagonism of class out of the classroom as well as out of the texts we read in that classroom. The point here is not that postcritique is apolitical; it is rather that it is liberal, the professoriat's contribution to making sure that our wealthy students do not understand the system that has made them

3 A characteristic instance would be Peter Frase (2014) acknowledging that class is "a structural relation," but only to remind us that it is "also an identity." Which is to say, it also "exists in its sociological sense," which means - and here his relief at having made it to neoliberal high ground is almost palpable - that "Classism is a real phenomenon" and that we should combat "classist attitudes."

4 The most recent figures show that $80 \%$ of students from the top quintile of wealth enroll in 4-year institutions, while students from the lowest quintile mainly enroll in two-year community colleges or in for profits; only $28 \%$ find their way to 4-year colleges (see https://www.insidehighered.com/news/ 2019/05/23/feds-release-broader-data-socioeconomic-status-and-college-enrollment-and-completion). When Felski teaches undergraduate classes at Virginia, two thirds of her students are from the top $20 \%$ (https://www.nytimes.com/interactive/projects/college-mobility/university-of-virginia) (13 March 2020). 
wealthy, and that their conception of social justice remains fixed on technologies of individualization: equality of opportunity, meritocracy, social mobility. ${ }^{5}$

Which is not to say that if we return to our original texts and our founding moment, the situation was much different. Actually, from this point of view, the new historicism was already a kind of crucial first step in the wrong direction. Catherine Gallagher (the other new historicist named by Jameson and writing in the same year as Fineman) explicitly and acutely disarticulates new historicism from what Marxism thought of as "the one conflict that counted: class conflict" (Gallagher 1989, 40) and connects it instead to the New Left, which she characterizes as "invoking the principle of individual and group [rather than class] liberation," and which she identifies as emerging out of "the problem of the constitution of the subject" (41) as reformulated in what was increasingly called post-Marxism. And The Gold Standard is no exception to this rule: although the word class appears with some frequency in it, the concept of class (much less class struggle) is pretty much absent. In fact, we could say that the thematics of the text - the impossibility or irrelevance of a certain resistance, as embodied in a passage like the following - precisely exemplify its preoccupation with what Gallagher calls "the constitution of modern subjectivity” (46).

Dreiser didn't so much approve or disapprove of capitalism; he desired pretty women in little tan jackets with mother-of-pearl buttons, and he feared becoming a bum on the streets of New York. These fears and desires were themselves made available by consumer capitalism, partly because a capitalist economy made it possible for lower class women to wear nice clothes and for middle-class men to lose their jobs, but more importantly because the logic of capitalism linked the loss of jobs to a failure of self-representation and linked the desirability of those women to the possibility of mimesis. Carrie is desirable, in this reading, because she herself desires - "to reproduce life," to make herself into a representation. And this insatiable appetite for representation Dreiser identifies with sexual promiscuity, corporate greed, and his own artistic practice. (Michaels 1987, 19)

This is precisely the kind of claim about the inescapability of the market that everyone - including me - thought of as the main new historicist point. And it is not exactly false. As long as you were looking for resistance to capitalism in the subject of capitalism, you were never going to find it. But if we understand the new historicism's aesthetics (the aesthetics of the bridge passage between concrete instances that turns explanation into tautology) as a refusal of text and context, of point of view, and thus of the subject, then we can see that refusal as a placeholder precisely

5 One reader of this text helpfully objected that it is unfair to single out postcritique in this way since the same criticism could be made of virtually everything done in the humanities at American universities, or at least everything except Marxist criticism. I agree! (Except that he forgot to include the social sciences.) But I think it is still worth granting a certain pride of place to postcritique, which in its allegiance to the idea that there is "no society" and that social analysis consists above all in "marveling at" and "attend[ing] to" the "ongoing connections, disconnections, and reconnections between countless actors" (and their families?) (Felski 2011, 578) does a much more thorough job of making class structure invisible even than intersectionality. 
for the non-intersubjective, non-relational structure of a capitalist society - for the conflict between capital and labor. In other words, class is excluded from the new historicism as a concept but gets into it as a 'writing convention,' and opposition gets into it not as a political position but as an entailment of its conception of 'elegance.' In this respect, we can not only say with Jameson that the polemical claim of the new historicism - the work of art's subsumption by the society it might be thought to critique - is really there just to motivate the device, we can say also that the device (the transitions) negates the motive. The new historicism had demonstrated, Gallagher wrote, that "the things in texts" which oppositional critics had hopefully identified as "subversive" and "destabilizing" were in fact "inscriptions of the formative moments, not the disruptions, of the liberal subject" (Gallagher $1989,45)$; the aesthetic of the transition negated this demonstration not exactly by showing that it was mistaken (there was indeed nothing oppositional about the destabilized subject) but by making it irrelevant.

Which is not to say that any of the Berkeley new historicists were politically interesting except insofar as we were early adopters of what today would be called left neoliberalism, and our interest in the history of the liberal subject was itself a component in the making of the neoliberal subject. As I noted above, we had no idea that we were participating in a profound transfer of wealth from the bottom $90 \%$ of the population to the top $10 \%$; our politics found expression in diversifying the western canon not in organizing a faculty union. And if you think of politics as mainly an expression of class interest, rightly so. We were not the faculty members who would need a union; we would be more the beneficiaries of that transfer of wealth than its victims. So both in its politics and in its intellectual commitment to the history of the subject, the new historicism belonged to that $90 \%$ of the world that, as the joke goes, is perfectly explained by vulgar Marxism. ${ }^{6}$

But in its aesthetics, in its 'writing practice,' not so much. In its literary critical form, vulgar Marxism - the debates over the gold standard made McTeague a dentist - was basically what Adorno condemned as the insufficiently mediated "materialistic determination of cultural traits," and the ambition of the new historicist aesthetic was to avoid the kind of separation between the two that would make the explanation of the one by the other look attractive. But Adorno also thought we could bridge this gap by running the whole thing through the "total social process" (Adorno 1980, 129) - italics his, presumably in the spirit of "we absolutely need to do this although we don't quite know how to do it and aren't completely sure what it is.”

One way, then, to see the new historicism is as a recognition of the problem Adorno identified, a rejection of his suggestion that it could only be solved by "theory," and the creation instead of an aesthetic designed not exactly to solve it, but to make it go away. That such an effort was bound to fail is obvious, just as the ongoing attraction to the idea that something is indeed explained by juxtaposing (but not de-

6 The joke is that sociology is interested only in the remaining $10 \%$. Hence Felski's "sociology envy." 
riving) our literary critical ambitions with (not from) our economic ones is also obvious. Jameson said that The Gold Standard differed from "standard New Historicist practice" in its commitment to a "total" (albeit "absent") "system," "the market" (Jameson 1991, 212). Perhaps the relevant point here is just - Jameson's point that the commitment to totality is the thing that is needed (even when you cannot totally figure out how it works) and that The Gold Standard's periodic imagination of this totality as necessarily "asphyxiating” (212) was a kind of sentimentalism.

If that is right, then the new historicist thematic was just the sad version of "there is no alternative" (postcritique would be not exactly the happy but the mindful version), and it is the contradictory relation this thematic had with its aesthetic that makes new historicism interesting. Why? Because by linking the history of the subject to the problem of the transition, new historicism also made it possible to see the replacement of the structural by the intersubjective, the formal by the relational, as a problem, and in this, it was itself, despite its mockery of the subversive and the oppositional, a kind of critique. Even, although none of its practitioners was a Marxist, a kind of Marxist critique, and especially by contrast to the ways in which most of what passes for critique has in fact been as embarrassingly uncritical as postcritique is proudly uncritical.

The title of the conference for which this paper was written and of the book for which it is being revised is Poetic Critique. My own way of understanding the "poetic" in that title has not been in terms of generic alternatives (not poetry or fiction or memoir as critique), but in terms of an aesthetic that might be made possible in the genre of literary criticism itself. By aesthetic - following Fineman and Jameson I have obviously meant something other than a method and also something more than a style, including a prose style. Obviously, I have not meant an aesthetic instead of a politics. But I also do not mean an aesthetic as a politics. Here we can see the very strict limits of poetic critique - a Marxism without Marxists had no political future, and the last half century has made it very clear that a class aesthetic cannot do the work of a class politics.

\section{Bibliography}

Adorno, Theodor. "Letters to Walter Benjamin." Aesthetics and Politics. With an Afterword by Fredric Jameson. London: Verso, 1980. 110-133.

Felski, Rita. "Nothing to Declare: Identity, Shame, and the Lower Middle Class." PMLA 115.1 (2000): 33-45.

Felski, Rita. “'Context Stinks!” New Literary History 42.4 (2011): 573-591.

Felski, Rita. The Limits of Critique. Chicago: University of Chicago Press, 2015.

Felski, Rita. "My Sociology Envy." Theory, Culture \& Society (25 July 2019). https://www.theoryculturesociety.org/rita-felski-my-sociology-envy/ (11 December 2019). Fineman, Joel. "The History of the Anecdote: Fiction and Fiction." The New Historicism. Ed. Harold Avram Veeser. London and New York: Routledge, 1989. 49-76.

Forster, E.M. Aspects of the Novel. Orlando: Mariner Books, 1956. 
Frase, Peter. "Stay Classy.” Jacobin (26 June 2014). https://jacobinmag.com/2014/06/stay-classy (5 May 2019).

Gallagher, Catherine. "Marxism and the New Historicism." The New Historicism. Ed. Harold Avram Veeser. London and New York: Routledge, 1989. 37-49.

Jameson, Fredric. Postmodernism or, The Cultural Logic of Late Capitalism. Durham, North Carolina: Duke, 1991.

Latour, Bruno. "On actor-network theory. A few clarifications plus more than a few complications." Soziale Welt 47.4 (1996).

http://transnationalhistory.net/interconnected/wp-content/uploads/2015/05/Latour-Actor-Network-Clarifications.pdf (13 March 2020).

Latour, Bruno. "Agency at the Time of the Anthropocene." New Literary History 35 (2014): 1-18. Michaels, Walter Benn. The Gold Standard and the Logic of Naturalism. Berkeley: University of California Press, 1987.

Michaels, Walter Benn. The Beauty of a Social Problem: Photography, Autonomy, Economy. London and Chicago: University of Chicago Press, 2015.

Sawaya, Francesca. "Safeguarding the Past: 'Presentist' Historicism." American Literary History 31.2 (2019): 301-311. 